Ekonomia - Wroclaw Economic Review 23/3 (2017)

Acta Universitatis Wratislaviensis

No 3807

DOI: 10.19195/2084-4093.23.3.11

\author{
Rafał Lipniewicz \\ Uniwersytet Wrocławski \\ Wydział Prawa, Administracji i Ekonomii \\ Instytut Nauk Ekonomicznych \\ rafal.lipniewicz@uwr.edu.pl
}

\title{
Międzynarodowe opodatkowanie emerytur - ujęcie modelowe
}

Artykuł nadesłany: 5 grudnia 2016 r.; artykuł zaakceptowany: 12 lutego 2017 r.

JEL Classification: K42, G2

Keywords: pensions, double taxation, residence principle, source principle

\begin{abstract}
International taxation of pensions - a model concept

Along with the changing demographic structure of many countries, especially developed ones, one of the significant social groups are people who receive benefits from old-age security. One aspect of this phenomenon is the issue of taxation of financial benefits received by pensioners in cross-border situations, in particular when during retirement pensions are paid out of a fund located in the territory of a different country from the one in which the beneficiary resides (tax residence). The taxpayer's right to tax such pensions is subject to negotiations between states that intend to conclude a double tax treaty, in which they will allocate tax power in this matter. These agreements are modeled on model conventions developed by the OECD and the UN. The purpose of this article is to analyze the legal, economic and administrative aspects resulting from modeled in the model conventions ways of allocating tax rights between the source of pension payment and the residential country of such a benefit.
\end{abstract}

\section{Systemy zabezpieczenia emerytalnego w kontekście międzynarodowej aktywności beneficjentów świadczeń emerytalnych - perspektywa podatkowa}

Jednym z efektów procesu globalizacji gospodarczej jest wzrost transgranicznej mobilności i zawodowej aktywności osób fizycznych, wyjeżdżających za granicę w celu świadczenia pracy. Z perspektywy konstrukcji systemów emerytalnych 
może to prowadzić do sytuacji, w których następuje „rozerwanie” tradycyjnego związku między państwem, w którym osoba fizyczna wykonywała pracę i z tego tytułu opłacała składki na poczet przyszłych świadczeń emerytalnych, a państwem, w którym zamieszkuje po uzyskaniu uprawnień emerytalnych. To z kolei rodzi pytanie o zasady rozdziału władztwa podatkowego pomiędzy państwem źródła wypłaty świadczenia emerytalnego a państwem rezydencji beneficjenta świadczenia. Rozstrzygnięcie tej kwestii utrudnia zauważalna „dysharmonia wynikająca $\mathrm{z}$ odrębnych rozwiązań stosowanych przez państwa $\mathrm{w}$ odniesieniu do emerytalnych systemów oszczędnościowych" (OECD 2016, s. 360). W niektórych państwach składki emerytalne korzystają z pewnych ulg podatkowych, które przybierają formę odłożonego w czasie podatku, co powoduje, że zarówno część dochodu osoby fizycznej wpłacona do funduszu emerytalnego, jak i dochód uzyskany przez fundusz, są wyłączone od podatku. Przyjmowane są również rozwiązania, w których dochody emerytalne płynące z tych funduszy podlegają opodatkowaniu przy ich wypłacie, podczas gdy inne państwa traktują składki emerytalne jako odmienną formę oszczędności i nigdy nie opodatkowują ani tych składek, ani ich zwrotu (OECD 2016, s. 361).

Rozdział uprawnień podatkowych w odniesieniu do dochodów z emerytur transgranicznych między państwami utrudnia też stosowanie w poszczególnych krajach zróżnicowanych systemów zabezpieczenia emerytalnego. Systemy te są ujmowane na ogół w trzech szerokich kategoriach: (1) bazowe (podstawowe) systemy zabezpieczeń socjalnych, (2) zakładowe (branżowe) systemy emerytalne oraz (3) indywidualne systemy emerytalne. Zazębianie się tych trzech kategorii systemów może mieć doniosłe konsekwencje w sferze podatkowej, w sytuacji gdy każde państwo ma odrębne zasady podatkowe co do składek płaconych na zabezpieczenie emerytalne, lecz także samych świadczeń emerytalnych (OECD 2016, s. 361). Ponadto w przypadku emerytalnych funduszy repartycyjnych (pracujący płaci składki na rzecz aktualnych emerytów) oraz emerytalnych funduszy kapitałowych (pracujący płaci składkę inwestowaną na rynku do czasu wypłacenia mu zebranych środków $\mathrm{w}$ formie emerytury) regułą jest zwolnienie $\mathrm{z}$ podatku wpłacanych składek emerytalnych (w przypadku funduszy kapitałowych również środków inwestowanych), a opodatkowanie wyłącznie świadczeń emerytalnych (Polarczyk 2008, s. 2).

Zasadniczo zabezpieczenie emerytalne ma zapewnić środki do zaspokojenia potrzeb w okresie starości, kiedy niemożliwe jest kontynuowanie aktywności zawodowej ze względu na wiek. Może być realizowane na różne sposoby i przez zróżnicowane podmioty, przy czym najpowszechniejszą zinstytucjonalizowaną jego formą są bazowe systemy emerytalne organizowane przez państwo. W założeniu emerytura bazowa powinna być emeryturą zaspokajającą podstawowe potrzeby i oferującą określony standard życia na starość (Rutecka 2014, s. 257-258). $\mathrm{Z}$ kolei dodatkowe (uzupełniające) systemy zabezpieczenia emerytalnego mają uzupełniać dochód oferowany przez systemy bazowe. Mogą występować zarów- 
no w formie obligatoryjnej, jak i dobrowolnej; w dodatku w niektórych systemach ubezpieczony może wystąpić z obowiązkowego systemu publicznego (jego części), jeśli jest objęty dodatkowym zabezpieczeniem zakładowym lub indywidualnym (Rutecka 2014, s. 257-258).

Zakładowe programy emerytalne $\mathrm{w}$ systemie prywatnych planów emerytalnych wyróżnia grupowy i powiązany z zatrudnieniem charakter uczestnictwa, który może wynikać także z relacji zawodowej łączącej uczestnika planu z podmiotem inicjującym program (sponsor programu). Programy te $\mathrm{z}$ reguły funkcjonują na zasadzie dobrowolności, dzięki czemu pracodawca ma swobodę podjęcia decyzji o utworzeniu programu; mogą jednak mieć również charakter obowiązkowy.

Natomiast indywidualne programy emerytalne mają z reguły charakter dobrowolnego, dodatkowego oszczędzania na poczet przyszłego zabezpieczenia emerytalnego i w zależności od wewnętrznych regulacji prawnych mogą przyjmować bardzo różne formy o charakterze ubezpieczeniowym bądź inwestycyjnym.

To zróżnicowanie systemów zabezpieczenia emerytalnego w poszczególnych państwach ma istotny wpływ na stosowanie postanowień międzynarodowych (najczęściej dwustronnych) umów o unikaniu podwójnego opodatkowania (dalej: umowy podatkowe), regulujących kwestię rozdziału władztwa podatkowego w odniesieniu do dochodów z emerytur pomiędzy umawiającymi się państwami. Umowy podatkowe wzorowane są na dwóch głównych konwencjach modelowych — OECD i ONZ, do których dołączone są oficjalne komentarze. Należy podkreślić, że ani konwencje modelowe, ani komentarze do nich nie stanowią źródła prawa, aczkolwiek uważa się je za będące kontekstem albo dodatkowym środkiem interpretacji umów o unikaniu podwójnego opodatkowania, zawieranych z wykorzystaniem postanowień wzorcowych zawartych w konwencjach. Nie ulega natomiast wątpliwości ich znacząca rola w zakresie wykładni umów o unikaniu podwójnego opodatkowania (Wyrok WSA we Wrocławiu 2015).

Zarówno konwencja modelowa OECD, jak i konwencja modelowa ONZ zawierają postanowienia odnoszące się do rozdziału władztwa podatkowego między państwami (art. 18) w zakresie transgranicznych emerytur. Obie konwencje posługują się pojęciem ,emerytura lub inne podobne świadczenie”, nie definiując go jednakże - dlatego umowy podatkowe wzorowane na konwencjach z reguły takich definicji również nie zawierają. W kontekście akcentowanego już znacznego zróżnicowania modeli systemów zabezpieczenia emerytalnego stosowanych w poszczególnych państwach pojawić się mogą uzasadnione wątpliwości, czy dane świadczenia wypłacane przez świadczeniodawcę z jednego państwa (państwa źródła) mogą być — w świetle właściwej umowy podatkowej — uznane przez państwo rezydencji beneficjenta tego świadczenia za emeryturę, do której zastosowanie znajdą postanowienia umowy podatkowej, regulujące, któremu z państw (źródła czy rezydencji) przysługuje wyłączne bądź częściowe uprawnienie do opodatkowania emerytury. 
Pewne wskazówki interpretacyjne dotyczące sposobu oceny charakteru danego świadczenia znajdują się w oficjalnych komentarzach do konwencji modelowych. W ramach wyjaśnień zawartych w komentarzu do OECD w zakresie pojęcia „emerytura” znajdują się nie tylko emerytury wypłacane bezpośrednio byłym pracownikom najemnym, lecz także innym beneficjentom (np. żyjącym współmałżonkom lub dzieciom pracowników), oraz inne podobne świadczenia, między innymi renty starcze z tytułu dawnego zatrudnienia.

Postanowienia konwencji modelowej OECD w zakresie emerytur mają zastosowanie tylko do wypłat związanych z zatrudnieniem w przeszłości; nie mają tym samym zastosowania na przykład do renty nabytej bezpośrednio przez rencistę z tytułu kapitału nagromadzonego poza funduszem emerytalnym związanym $\mathrm{z}$ zatrudnieniem. Artykuł 18 konwencji modelowej OECD ma zastosowanie bez względu na podatkowe traktowanie funduszu, z którego pochodzą wypłaty. Tak więc świadczenie dokonywane na podstawie systemu emerytalnego, który nie podlega ulgom podatkowym, może stanowić „emeryturę lub inne podobne świadczenie" (OECD 2016, s. 360).

Pewną wskazówką do interpretacji pojęcia emerytury mogą być postanowienia umów podatkowych, z których wynika, że pojęcia niezdefiniowane w samej umowie należy rozumieć zgodnie z postanowieniami prawa wewnętrznego poszczególnych państw w zakresie podatków (Pogoński 2016, s. 383), pod warunkiem że z kontekstu umowy nie wynika inaczej. Interpretacji terminów dokonuje się wówczas w oparciu o prawo tego państwa, któremu umowa przyznaje prawo do opodatkowania świadczenia (Uss 2010, s. 1037).

W świetle ogólnej dyrektywy interpretacyjnej - przyjętej w komentarzu do konwencji modelowej OECD - to, czy określone wypłaty mieszczą się w zakresie przedmiotowym art. 18 konwencji, regulującego opodatkowanie emerytur, winno się analizować ze względu na ich charakter płatności, uwzględniając przy tym „fakty i okoliczności, w których są dokonywane” (OECD 2016, s. 361). Komentarz zawiera ponadto dwie szczegółowe wytyczne interpretacyjne. Pierwsza odnosi się znaczenia i wzajemnych relacji użytych w konwencji pojęć „emerytura” oraz „inne podobne świadczenie” — o ile bowiem określenie ,emerytura" w ramach zwykłego znaczenia tego słowa obejmuje tylko okresowe wypłaty, o tyle sformułowanie ,inne podobne świadczenia” jest na tyle szerokie, aby objąć wypłaty nieokresowe. Na przykład wypłata ryczałtowa w miejsce wypłat okresowych dokonana w momencie ustania zatrudnienia może wchodzić w zakres stosowania tego artykułu (OECD 2016, s. 361).

To, czy konkretną wypłatę należy uważać za inne świadczenie podobne do emerytury lub końcowe wynagrodzenie za wykonywaną pracę — objętą art. 15 konwencji modelowej OECD - należy oceniać w odniesieniu do konkretnych okoliczności faktycznych. Na przykład jeżeli wykaże się, że powodem wypłaty ryczałtowej jest przeliczenie emerytury lub rekompensata za zmniejszoną emeryturę, wówczas daną wypłatę można określić jako „inne podobne świadczenie”. 
Mogłoby to mieć miejsce na przykład wówczas, gdy osoba w momencie przejścia na emeryturę miała możliwość wyboru między wypłacaniem emerytury a kwotą ryczałtową obliczoną w powiązaniu z ogólną kwotą składek lub kwotą emerytury, do której byłaby uprawniona według obowiązujących zasad w zakresie systemu emerytalnego (OECD 2016, s. 362).

W związku z tym wskazuje się, iż emerytura (o ile sama umowa o unikaniu nie stanowi inaczej) jest świadczeniem pieniężnym związanym z wykonywaną wcześniej aktywnością zarobkową, czy to w ramach umowy o pracę, samozatrudnienia, czy innej, od której uiszczane były składki na ubezpieczenie emerytalne (Pogoński 2016, s. 383). Celem wypłat świadczeń powinno być przede wszystkim zapewnienie byłemu pracownikowi, począwszy od chwili zaprzestania wykonywania przez niego pracy zarobkowej, środków zabezpieczających potrzeby pracownika oraz jego rodziny. Wypłata emerytury ma bowiem niejako zrekompensować utratę źródła przychodów z powodu zakończenia stosunku pracy oraz zaspokoić potrzeby związane na przykład z opieką w starszym wieku lub z dalszą niezdolnością do pracy (Bobkiewicz 2007, s. 390). Coraz częściej występującym zjawiskiem jest pozostawanie uczestnikiem systemu zabezpieczenia emerytalnego w czasie trwania zatrudnienia w jednym państwie, a następnie zmiana rezydencji podatkowej poprzez wybór miejsca zamieszkania w innym państwie w okresie pobierania świadczeń emerytalnych. Taka sytuacja wymaga uzgodnienia między zainteresowanymi państwami kwestii podziału uprawnień do opodatkowania podatkiem dochodowym tego typu świadczeń transgranicznych.

\section{Zasady rozdziału władztwa podatkowego w odniesieniu do emerytur w konwencjach modelowych - przesłanki i konsekwencje}

Podstawowym celem umów podatkowych, wzorowanych powszechnie na konwencjach modelowych OECD i ONZ, jest uzgodnienie między umawiającymi się państwami rozdziału ich władztwa podatkowego w stosunku do osób, rzeczy i zdarzeń (czynności), których obecność bądź aktywność skutkuje powstaniem zobowiązania podatkowego, w sytuacji gdy element(-y) podatkowoprawnego stanu faktycznego mają charakter transgraniczny (Harris, Olivier 2010, s. 18). Do wyznaczenia zakresu władztwa podatkowego państwa stosują różne metody regulacji, które na ogół oparte są na zasadzie rezydencji lub źródła. Zasada rezydencji oznacza, iż państwo ma kompetencję do opodatkowania globalnych dochodów podmiotu uznanego za rezydenta podatkowego, bez względu na miejsce (lokalizację) źródeł, z których dochody te zostały uzyskane. Natomiast w świetle zasady źródła państwo ma prawo opodatkować dochody uzyskiwane na jego terytorium, bez względu na to, czy są osiągane przez rezydentów, czy nierezydentów podatkowych. 
Kwestię rozdziału władztwa podatkowego w zakresie emerytur regulują odpowiednio art. 18 konwencji modelowej OECD (dalej: KM OECD) oraz art. 18 konwencji modelowej ONZ (dalej: KM ONZ). Zgodnie z art. $18 \mathrm{KM} \mathrm{OECD,} \mathrm{z} \mathrm{za-}$ strzeżeniem postanowień art. 19 ust. 2 (emerytury wypłacane funkcjonariuszom publicznym), emerytury i inne podobne świadczenia wypłacane osobie będącej rezydentem umawiającego się państwa w związku z jej wcześniejszym zatrudnieniem będą podlegały opodatkowaniu wyłącznie w tym państwie. Oznacza to, że na gruncie konwencji modelowej OECD prawo do opodatkowania emerytur i innych podobnych świadczeń przysługuje jedynie państwu rezydencji beneficjenta świadczenia emerytalnego (Kukulski 2015, s. 214-218).

Ten przyjęty przez OECD prymat zasady rezydencji nie ma jednak charakteru absolutnego. Komentarz do konwencji modelowej OECD podaje cztery alternatywne do wzorca zawartego w samej konwencji, przykładowe postanowienia umów podatkowych, opisujące możliwe sposoby zabezpieczenia prawa państwa źródła w kontekście opodatkowania emerytur transgranicznych: (1) opodatkowanie emerytur wyłącznie w państwie ich źródła; (2) umożliwienie państwu źródła opodatkowania ich w sposób niewyłączny; (3) przyznanie państwu źródła prawa do ograniczonego opodatkowania oraz (4) zezwolenie państwu źródła na opodatkowanie emerytury dopiero wówczas, gdy nie podlega ona opodatkowaniu w państwie rezydencji (Uss 2010, s. 1038).

Z kolei cechą charakterystyczną postanowień wzorcowych konwencji modelowej ONZ jest przyjęcie dwóch alternatywnych zalecanych unormowań kwestii opodatkowania emerytur w umowach podatkowych. Zgodnie z pierwszą alternatywą (art. 18a) emerytury i inne podobne świadczenia wypłacane osobie zamieszkującej $\mathrm{w}$ umawiającym się państwie z tytułu jej wcześniejszej pracy najemnej podlegają opodatkowaniu tylko w tym państwie, w którym znajduje się miejsce zamieszkania odbiorcy emerytury. Podkreśla się w tym kontekście, iż przyznanie wyłącznego prawa do opodatkowania określonej kategorii dochodów (przychodów) wyłącznie państwu źródła należy do rozwiązań stosowanych niezwykle rzadko w konwencjach modelowych i wzorowanych na nich umowach podatkowych (Kukulski 2015, s. 214-218). Zgodnie z drugą proponowaną w KM ONZ (art. 18b) wzorcową opcją dla państw zawierających umowy podatkowe emerytury i inne podobne świadczenia wypłacane osobie będącej rezydentem umawiającego się państwa w związku z jej wcześniejszym zatrudnieniem mogą podlegać opodatkowaniu w państwie rezydencji beneficjenta, jednakże mogą być również przedmiotem opodatkowania w państwie ich źródła, jeżeli ich wypłata jest dokonywana przez podmiot będący rezydentem państwa źródła bądź zakład zagraniczny usytuowany w tym państwie. W wypadku alternatywy z art. 18b KM ONZ oba państwa-strony umowy podatkowej (źródła i rezydencji) mają zatem prawo do opodatkowania emerytur oraz innych podobnych świadczeń (ang. sharing of taxing rights). Jeśli więc emerytura lub inne podobne świadczenie zostało opodatkowane w państwie źródła, państwo rezydencji beneficjenta emerytury 
lub innego podobnego świadczenia — w zależności od rozwiązań wynikających $\mathrm{z}$ krajowych regulacji podatkowych $\mathrm{w}$ tym zakresie - zastosuje przewidzianą w bilateralnej umowie zawartej z państwem źródła emerytury metodę unikania podwójnego opodatkowania (Kukulski 2015, s. 214-218).

Kwestia przyznania prymatu opodatkowania emerytur państwu źródła ich wypłat bądź rezydencji ich beneficjentów w sytuacjach transgranicznych ma niewątpliwie kontekst nie tylko podatkowoprawny, lecz także ekonomiczno-społeczny. Poszukując zatem argumentów za opodatkowaniem wypłacanych emerytur w państwie rezydencji, co jako preferowane rozwiązane proponuje konwencja modelowa OECD (oraz KM ONZ w alternatywie pierwszej), można wskazać argumenty natury podatkowej, wśród których szczególnie eksponowana jest kwestia uwzględnienia tak zwanej zasady zdolności świadczenia (ang. ability to pay). Zgodnie z nią podatki powinny być nakładane na podmioty w taki sposób, aby uwzględniać ich możliwości dochodowe do realizacji zobowiązań podatkowych, bez uwzględniania ewentualnych świadczeń publicznych, z których mogą korzystać. Osoby o porównywalnej zdolności świadczenia powinny zatem w podobnej wysokości łożyć na finansowanie świadczeń publicznych (Grassi 2015, s. 14). Zdolność do świadczenia uzależniona jest między innymi od wysokości całkowitego dochodu osiąganego przez podatnika, jego sytuacji rodzinnej czy okoliczności osobistych. Właściwa ocena tych czynników może zatem umożliwić zastosowanie odpowiednich stawek podatku oraz ewentualnie przyznania ulg podatkowych (Uss 2010, s. 1040-1041). W tym kontekście zasada rezydencji, w świetle której przedmiotem opodatkowania jest całość dochodów podatnika (osiąganych w skali międzynarodowej), uznawana jest za spełniającą w większym stopniu postulat respektowania zasady zdolności świadczenia podatnika — znając bowiem całościowy obraz sytuacji majątkowej i dochodowej podatnika (osoby fizycznej), podmiot nakładający podatek może poprzez odpowiednio skonstruowane regulacje prawne łagodzić bądź zaostrzać jego obciążenia fiskalne, dostosowując je do jego sytuacji osobistej.

W wypadku emerytur można jednak mieć wątpliwości co do zasadności tej argumentacji. Zwykle bowiem emerytury stanowią jedyne (bądź zdecydowanie dominujące) źródło dochodów osób, które nabyły uprawnienia emerytalne. Oznacza to, iż z punktu widzenia ich sytuacji dochodowej podobnej oceny ich zdolności świadczenia może dokonać zarówno państwo rezydencji emeryta, jak i państwo źródła dochodów emerytalnych. Zaburzeniem tej porównywalności sytuacji może być sytuacja majątkowa emeryta, jeżeli oprócz dochodów z emerytury czerpie on dochody z majątku zlokalizowanego w państwie rezydencji, których nie uwzględni państwo źródła wypłaty emerytur, dokonując opodatkowania takich dochodów.

Interesującą propozycję uwzględnienia zasady zdolności świadczenia w przypadku przyznania prawa do opodatkowania emerytur państwu źródła zawiera komentarz do konwencji modelowej OECD, w świetle którego państwo źródło wypłaty emerytury mogłoby zgodzić się na przyznanie rezydentowi drugiego pań- 
stwa (rezydencji podatnika) osobistych ulg i zwolnień podatkowych, takich jak przyznawane własnym rezydentom podatkowym, w proporcji, w jakiej dochód z emerytury pozostaje względem całości dochodów uzyskiwanych przez beneficjenta świadczenia. Takie rozwiązanie wymaga jednak bardzo dobrej współpracy między organami podatkowymi obu państw, tak aby państwo źródła mogło we właściwy sposób ustalić zakres ulg i zwolnień możliwych do przyznania beneficjentowi świadczenia emerytalnego, będącego rezydentem innego państwa (strony umowy podatkowej).

Argumentem za oparciem opodatkowania transgranicznych transferów emerytur na zasadzie rezydencji jest również minimalizowanie obciążeń natury administracyjnej, nakładanych na beneficjenta świadczenia emerytalnego. Opodatkowanie w kraju jego rezydencji, bez względu na położenie źródeł pochodzenia świadczenia emerytalnego, pozwala uniknąć konieczności dopełnienia formalności administracyjnych związanych z koniecznością zapłaty podatku w innym państwie, co szczególnie eksponuje się w odniesieniu do sytuacji, w których emerytury na rzecz tego samego beneficjenta wypłacane są z funduszy kilku państw, w których emeryt w czasie ich otrzymywania nie jest już rezydentem podatkowym (Uss 2010, s. 1040-1041).

Za opodatkowaniem emerytur transgranicznych w państwie rezydencji przemawiać może również chęć zagwarantowania jednolitego poziomu opodatkowania dla dochodów pochodzących przedmiotowo z tego samego źródła, bez względu na miejsce jego faktycznej lokalizacji. Może to mieć szczególne znaczenie dla spójności systemu podatkowego państwa rezydencji podmiotu otrzymującego świadczenia emerytalne pochodzące z zagranicy. Państwo rezydencji może bowiem stosować filozofię obciążeń fiskalnych opartą głównie na podatkach pośrednich (VAT i akcyza), przy niskim bądź umiarkowanym poziomie obciążeń dochodów (przychodów). Jeżeli zatem państwo źródła ucieka się do odmiennej filozofii, wówczas dochody z emerytur byłyby obciążone wysokim podatkiem dochodowym w państwie źródła oraz wysokim podatkiem od konsumpcji w państwie rezydencji, co może niezwykle negatywnie wpływać na sytuację podatkową netto emerytów pobierających zagraniczne świadczenia.

Wśród praktycznych wątpliwości jest także kwestia ustalenia kryteriów zdefiniowania państwa źródła w kontekście wypłacanych świadczeń emerytalnych. Możliwe jest bowiem przyjęcie założenia, iż państwem źródła jest to, na którego terytorium znajduje się fundusz (publiczny bądź prywatny), z którego wypłacane są emerytury, bądź iż za takie państwo należy uznać to, w którym wykonywana była wcześniej praca, stanowiąca źródło płaconych składek emerytalnych.

Mimo niewątpliwej wagi powyższych argumentów przedstawiane są również przesłanki przeciwne, wskazujące na prawne, ekonomiczne i administracyjne aspekty przemawiające za opodatkowaniem emerytur transgranicznych $\mathrm{w}$ państwie, z którego terytorium są wypłacane (państwie źródła). Wynika to chociażby z faktu, iż emerytury traktowane są jako forma „odroczonej rekompensaty” za 
usługi świadczone w państwie źródła wypłaty świadczeń emerytalnych. Państwa, które umożliwiają odliczanie składek płaconych przez osoby zatrudnione na zabezpieczenie emerytalne, liczą bowiem na jego „odzyskanie” w czasie wypłaty świadczeń emerytalnych; jednakże państwo źródła ich wypłaty — w wypadku przyjęcia zasady rezydencji - nie ma możliwości ich opodatkowania, a jednocześnie odraczany w czasie podatek zostanie opodatkowany w państwie, które nie przyznawało tego typu korzyści podatkowych, a mimo to czerpać będzie korzyści w postaci wpływów do budżetu z tytułu opodatkowania emerytur zagranicznych. Może też dochodzić do tak zwanego niezamierzonego podwójnego nieopodatkowania emerytur w sytuacjach, w których państwo rezydencji w ramach wewnętrznego systemu podatkowego nie przewiduje opodatkowania emerytur - wówczas nie będą one opodatkowane w żadnym z państw (Narkiewicz-Tarłowska 2011, s. 397).

Wśród argumentów wysuwane są również te nawiązujące do zjawiska unikania opodatkowania. Jeżeli bowiem opodatkowanie emerytur następuje tylko w państwie rezydencji podatnika, istnieje ryzyko, iż dochodów z tego tytułu podatnik nie wykaże do opodatkowania, licząc, iż państwo źródła nie posiada informacji o zagranicznym źródle, z którego wypłacane są świadczenia emerytalne, co pozwoli podatnikowi uchylić się od spełnienia należnego zobowiązania podatkowego. Jeśli wymiana informacji dla celów podatkowych między zainteresowanymi państwami nie jest — mimo istnienia podstaw prawnych — właściwie realizowana, takie zagrożenie może się zmaterializować.

Argumentem za opodatkowaniem emerytur transgranicznych w państwie źródła może być ponadto chęć przeciwdziałania zjawisku „ucieczki przed opodatkowaniem" i migracjami beneficjentów świadczeń emerytalnych z państw, w których - dzięki dobrze zaprojektowanemu i efektywnemu systemowi emerytalnemu, a także sytuacji makroekonomicznej skutkującej wysokimi wynagrodzeniami, z których odprowadzane były znaczące składki na przyszłe zabezpieczenie emerytalne - osoby te uzyskały prawo do wysokich świadczeń emerytalnych, do państw, których system podatkowy i poziom wynagrodzeń nie pozwoliłyby na tak wysokie świadczenia, które nieopodatkowane podatkiem u źródła ich wypłaty, mimo iż zostaną zwolnione (preferencyjnie opodatkowane) z podatku dochodowego na podstawie wewnętrznych regulacji, to $\mathrm{z}$ ekonomicznego punktu widzenia będą stanowiły strumień wydatków ponoszonych w państwie zamieszkania emeryta, co może mieć wpływ zarówno na wysokość pobieranego podatku VAT i akcyzy w państwie rezydencji, jak i generalnie stanowić jeden z czynników (konsumpcja) wpływających na wysokość PKB państwa rezydencji.

Ta wieloaspektowa argumentacja, przemawiająca za opodatkowaniem wypłacanych emerytur transgranicznych zarówno w państwie rezydencji ich beneficjenta, jak i państwie źródła ich powstania w praktyce traktatowej skutkuje modyfikacjami wzorców modelowych zawartych w konwencjach OECD i ONZ na rzecz specyficznych, odbiegających od modelowych rozwiązań rozdziału władztwa podatkowego między państwami źródła i rezydencji. Wynika to rów- 
nież ze zróżnicowanych systemów zabezpieczenia emerytalnego funkcjonujących w poszczególnych państwach, co powoduje, iż oparcie rozdziału władztwa podatkowego wyłącznie na jednej z analizowanych zasad mogłoby skutkować podwójnym opodatkowaniem podatników otrzymujących emerytury zagraniczne bądź niezamierzonym podwójnym nieopodatkowaniem tych świadczeń.

\section{Wnioski}

Transgraniczne wypłaty świadczeń emerytalnych są jednym z elementów wzorcowych postanowień ujętych w konwencjach modelowych OECD i ONZ, na których wzorują się państwa zawierające umowy o unikaniu podwójnego opodatkowania. Zasadniczo praktyka traktatowa państw w niewielkim stopniu odbiega od postanowień wzorcowych. Wyjątkiem są regulacje dotyczące opodatkowania emerytur. Wynika to z tego, iż zróżnicowanie systemów zabezpieczenia społecznego jest w poszczególnych państwach tak duże, że przy podziale władztwa podatkowego między państwem źródła dochodów emerytalnych a państwem rezydencji ich beneficjenta ich uwzględnienie wymusza zastosowanie rozwiązań odbiegających od modelowych, tak aby zabezpieczyć interesy fiskalne umawiających się państw.

\section{Bibliografia}

Bobkiewicz K. (2007), Komentarz do art. 18, [w:] Umowa o unikaniu podwójnego opodatkowania $z$ Niemcami, red. M. Jamroży, A. Cloer, Warszawa, s. 382-399.

Grassi C. (2015), Status and Impact of the Ability to Pay Principle in the ECJ's Case Law Concerning Tax Benefits Based on Personal and Family Circumstances, CFE Working Papers series, nr 52, www.cfe.lu.se, s. 2-41.

Harris P., Olivier D. (2010), International Commercial Tax, New York.

Kukulski Z. (2015), Konwencja modelowa OECD i konwencja modelowa ONZ w polskiej praktyce traktatowej, Warszawa.

Narkiewicz-Tarłowska J. (2011), Opodatkowanie emerytur, [w:] Umowy o unikaniu podwójnego opodatkowania. Komentarz, red. M. Zasiewska, A. Oktawiec, J. Chorązka, Warszawa, s. 395-415.

OECD (2014), Modelowa konwencja w sprawie podatku od dochodu i majątku. Wersja skrócona 15 lipca 2014, Warszawa.

Pogoński M. (2016), Opodatkowanie emerytur i rent zagranicznych, [w:] Opodatkowanie dochodów transgranicznych, red. M. Jamroży, Warszawa, s. 380-390.

Polarczyk K. (2008), Opodatkowanie świadczeń emerytalno-rentowych w krajach członkowskich UE oraz w Szwajcarii, Kanadzie i USA, „Analizy BAS” 1, s. 2-6.

Rutecka J. (2014), Dodatkowe zabezpieczenia emerytalne - charakterystyka i czynniki rozwoju, „Prace Naukowe Uniwersytetu Ekonomicznego we Wrocławiu 2014” 342, s. 256-266.

Uss. M. (2010), Komentarz do artykułu 18, [w:] Model konwencji OECD. Komentarz, red. B. Brzeziński, Warszawa, s. 1033-1062.

Wyrok Wojewódzkiego Sądu Administracyjnego we Wrocławiu z dnia 2 lutego 2016 roku, sygn. I SA/ Wr 1510/15, http://orzeczenia.nsa.gov.pl/cbo/query (dostęp: 30.09.2017).

Ekonomia - Wroclaw Economic Review 23/3 (2017)

(C) for this edition by CNS 